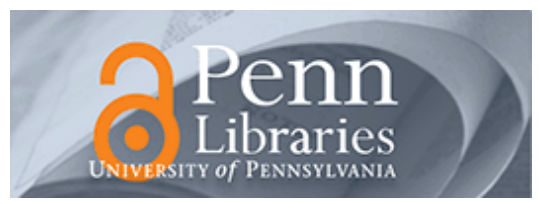

University of Pennsylvania

ScholarlyCommons

\title{
Chapter 3 The Impact of the Corporate Leniency Program on Cartel Formation and the Cartel Price Path
}

Joe Chen

Joseph E. Harrington Jr

University of Pennsylvania

Follow this and additional works at: https://repository.upenn.edu/bepp_papers

Part of the Business Commons, Economics Commons, and the Public Affairs, Public Policy and Public Administration Commons

\section{Recommended Citation}

Chen, J., \& Harrington, J. E. (2007). Chapter 3 The Impact of the Corporate Leniency Program on Cartel Formation and the Cartel Price Path. Contribution to Economic Analysis, 282 59-80. http://dx.doi.org/ 10.1016/S0573-8555(06)82003-1

At the time of publication, author Joseph E. Harrington Jr. was affiliated with the John Hopkins University. Currently, he is a faculty member in the Business, Economics and Public Policy Department of the Wharton School at the University of Pennsylvania.

This paper is posted at ScholarlyCommons. https://repository.upenn.edu/bepp_papers/21

For more information, please contact repository@pobox.upenn.edu. 


\title{
Chapter 3 The Impact of the Corporate Leniency Program on Cartel Formation and the Cartel Price Path
}

\author{
Abstract \\ Previous research exploring the effect of corporate leniency programs has modeled the oligopoly stage \\ game as a Prisoners' Dilemma. Using numerical analysis, we consider the Bertrand price game and allow \\ the probability of detection and penalties to be sensitive to firms' prices. Consistent with earlier results, a \\ maximal leniency program necessarily makes collusion more difficult. However, we also find that partial \\ leniency programs - such as in the U.S. - can make collusion easier compared to offering no leniency. We \\ also show that even if cartel formation is not deterred, a leniency program can reduce the prices charged \\ by firms.

\section{Disciplines} \\ Business | Economics | Public Affairs, Public Policy and Public Administration

\section{Comments} \\ At the time of publication, author Joseph E. Harrington Jr. was affiliated with the John Hopkins University. \\ Currently, he is a faculty member in the Business, Economics and Public Policy Department of the \\ Wharton School at the University of Pennsylvania.
}




\title{
The Impact of the Corporate Leniency Program on Cartel Formation and the Cartel Price Path*
}

\author{
Joe Chen \\ Faculty of Economics \\ University of Tokyo \\ 7-3-1 Hongo, Bunkyo-ku \\ Tokyo, 113-0033 Japan \\ joechen@e.u-tokyo.ac.jp \\ Joseph E. Harrington, Jr. \\ Department of Economics \\ Johns Hopkins University \\ Baltimore, MD 21218 USA \\ 410-516-7615, -7600 (Fax) \\ joe.harrington@jhu.edu
}

December 5, 2005

\begin{abstract}
Previous research exploring the effect of corporate leniency programs has modelled the oligopoly stage game as a Prisoners' Dilemma. Using numerical analysis, we consider the Bertrand price game and allow the probability of detection and penalties to be sensitive to firms' prices. Consistent with earlier results, a maximal leniency program necessarily makes collusion more difficult. However, we also find that partial leniency programs - such as in the U.S. - can make collusion easier compared to offering no leniency. We also show that even if cartel formation is not deterred, a leniency program can reduce the prices charged by firms.
\end{abstract}

*This paper was written for Political Economy of Antitrust, Vivek Ghosal and Johan Stennek, editors, North-Holland, forthcoming. The authors thank Giancarlo Spagnolo for suggesting this research topic and the comments of two anonymous referees. The first author acknowledges the support of the 21st Century Center of Excellence (COE) Program at the Graduate School of Economics of the University of Tokyo. The second author acknowledges the support of the National Science Foundation under grant SES-0209486. 


\section{Introduction}

One of the most important policy developments in antitrust policy in recent decades is the revision of the Corporate Leniency Program by the U.S. Department of Justice (DOJ) in 1993. Originally instituted in 1978, this program allows corporations and individuals, who were engaging in illegal antitrust activity (such as price-fixing), to receive amnesty from government penalties. This means that a corporation can avoid government fines, while individuals escape fines and prison sentences. The 1993 revision made it possible for amnesty to be awarded even when an investigation had been started and made it a condition that the DOJ "has not received information about the illegal activity being reported from any other source." This means that amnesty is limited to one firm per cartel. Leniency programs have proliferated as the European Commission instituted one in 1996 and an increasing number of industrialized countries have some form of leniency program. While it is difficult to assess the role of these programs on cartel formation and collapse, we do know that it has been widely used. Notable examples include Rhône-Poulenc in the vitamins case, Christie's in the fine arts auctions case, and Carbide/Graphite in the graphite electrodes case. ${ }^{1}$

In light of the influence of leniency programs, it is not surprising that there has been a growing amount of research exploring how such programs destabilize collusion. Recent work includes Aubert, Kovacic, and Rey (2003), Motta and Polo (2003), Spagnolo (2003), Feess and Walzl (2004), Motchenkova (2004), and Harrington (2005a). This research has generally shown that leniency does reduce cartel stability. In the context of a stationary environment (that is, the probability of conviction without use of the leniency program is fixed over time), Spagnolo (2003) shows that, if there is a budget-balancing constraint, a first-best solution can be achieved by giving the first firm to come forward a reward equal to the fines levied on the remaining firms. Motta and Polo (2003) allow the probability of conviction to stochastically change over time though it is restricted to take only two values, one of which is zero (which corresponds to the event that there is no investigation). Their analysis provides qualified support for leniency. In some cases, waiving a sufficiently high fraction of penalties can prevent cartel formation, in which case such a policy is optimal. However, if it cannot prevent cartel formation then no leniency should be provided. Harrington (2005a) also allows the probability of detection and conviction to vary over time but it can take any value from $[0,1]$. This introduces a new effect absent

\footnotetext{
${ }^{1}$ A good review of the status of leniency programs is provided in "Hard Core Cartels" (2003). A critical description of the U.S. program can be found in Kobayashi (2001).
} 
from Motta and Polo (2003) which has the implication that, under certain conditions, more leniency can enhance cartel stability. It is then possible for partial leniency to be optimal though plausible sufficient conditions are provided for it to be optimal to waive all penalties for the first firm to come forward. It is also shown that restrictions should be placed on when amnesty is awarded, though it can be optimal to award amnesty even when the antitrust authority is very likely to win the case without insider testimony.

A common limitation to all of this research is that the impact of leniency programs is explored in a restrictive setting: The stage game modelling oligopolistic interaction is the Prisoners' Dilemma. This means that the collusive price and profit are fixed, as are the price and profit associated with a firm cheating on the cartel. It has the implication that the probability of the cartel being discovered is exogenous to how the cartel behaves as is the penalty in the event of discovery and successful prosecution. All of these restrictions affect the influence of a leniency program. While a leniency program may be able to prevent cartel formation, by fiat it cannot impact the cartel price in the event a cartel forms. Furthermore, while a leniency program may prevent cartel formation when the collusive price path is fixed (as it is with the Prisoners' Dilemma), it may not be able to do so if firms can strategically adjust the cartel price path so as to counteract the destabilizing effect of a leniency program. Previous work has shown that leniency programs destabilize cartels by tightening the incentive compatibility constraint and the issue is to what extent can a strategically-minded cartel counteract it by appropriately lowering the proposed collusive price path.

The objective of this paper is to explore the implications of the corporate leniency program in a rich dynamic model that endogenizes the prices that firms charge and allows the probability of detection and penalties to be sensitive to those prices. With this model, we can re-examine the central question thus far explored in the leniency program literature: Do leniency programs make collusion more difficult? In addition, we can also explore a new question: If a leniency program does not prevent cartel formation, what is its impact on the cartel price path?

To engage in this exercise, we draw upon another recent strand of the collusion literature that adapts the classical repeated game model of collusion to allow for a cartel to be discovered and, in that event, penalties being levied (Harrington, 2004, 2005b; Harrington and Chen, 2005). This work allows both the probability of detection and penalties to be endogenous to colluding firms' prices. A cartel is then modelled as choosing a price path to maximize the expected present value of profits while taking into account how this price 
path impacts the likelihood of paying penalties and satisfying the usual incentive compatibility constraint ensuring the internal stability of the cartel. A cartel then selects a price path that ensures compliance from all firms and which tries to avoid raising suspicions that they are colluding. In that setting, the introduction of a leniency program will impact the price path through its influence on the incentive compatibility constraints. Leniency may influence whether or not collusion is stable and, when it is stable, the properties of the collusive price path.

In sum, this paper brings together two recent strands in the collusive pricing literature - research that explores the impact of corporate leniency programs and research that explores the impact of antitrust enforcement on cartel formation and the collusive price path. In doing so, we generate two primary findings. First, the optimality of a maximally lenient policy, which has been derived in earlier studies, is shown to be robust to when the cartel can adjust its price to the leniency policy and when both the probability of detection and penalties are sensitive to the collusive price path. Second, a policy of partial leniency - which is in effect in the U.S. - can actually make collusion easier and result in a higher cartel price path, relative to a policy of no leniency. After laying out the model in Section 2 , an optimal collusive price path is defined in Section 3. The impact of leniency programs is analyzed in Section 4, while Section 5 concludes.

\section{Model}

The model is a special case of that in Harrington (2004) with the exception that we allow for a corporate leniency program. As the analysis in this paper will be numerical, functional forms will be specified. For motivation and elaboration of many assumptions, the reader is referred to Harrington (2005b).

Consider an industry with $n \geq 2$ symmetric firms. To keep matters simple, assume the stage game is the Bertrand price game so that firms offer homogeneous products, make simultaneous price decisions, and have constant marginal cost, denoted $c \geq 0$. Firm $i$ 's profit when its price is $P_{i}$ and all other firms charge a common price of $P_{-i}$ is

$$
\pi_{i}\left(P_{i}, P_{-i}\right)= \begin{cases}\left(P_{i}-c\right)\left(a-b P_{i}\right) & \text { if } P_{i}<P_{-i} \\ \left(P_{i}-c\right)(1 / n)\left(a-b P_{i}\right) & \text { if } P_{i}=P_{-i} \\ 0 & \text { if } P_{i}>P_{-i}\end{cases}
$$

where $(a-b P)$ is market demand at a price of $P$ and it is assumed $a-b c>0$. Of course, the stage game equilibrium has all firms price at $c$ with associated profit of $\widehat{\pi}=0$. Finally, 
let $\pi(P) \equiv(P-c)(1 / n)(a-b P)$ denote a firm's profit when all firms charge a common price.

Firms engage in this price game for an infinite number of periods. The setting is one of perfect monitoring which means firms' prices over the preceding $t-1$ periods are common knowledge in period $t$. In this paper, "detection" always refers to a third party, such as buyers, detecting the existence of a cartel. Assume a firm's payoff is the expected discounted sum of its income stream where the common discount factor is $\delta \in(0,1)$.

If firms form a cartel, they meet to determine price. Assume these meetings, and any associated documentation, provides the "smoking gun" if an investigation is pursued. The cartel is detected with some probability and incurs penalties in that event. Assume, for simplicity, that detection results in the discontinuance of collusion forever. Detection in period $t$ then generates a terminal payoff of $[\widehat{\pi} /(1-\delta)]-X^{t}-F\left(=-X^{t}-F\right)$ where $X^{t}$ is a firm's damages and $F$ is any (fixed) fines (which may include the monetary equivalent of prison sentences). ${ }^{2}$ If not detected, collusion continues on to the next period. It is useful to think of $X^{t}+F$ as a "hidden liability" for a firm which is incurred only in the event that the cartel is discovered. As we'll be focusing upon symmetric equilibria, all firms will have the same damages so there is a single damage state variable.

Damages are assumed to evolve in the following manner:

$$
X^{t}=\beta X^{t-1}+\gamma x\left(P^{t}\right) \text { where } \beta \in[0,1) \text { and } \gamma \geq 0 .
$$

As time progresses, damages incurred in previous periods become increasingly difficult to document and $1-\beta$ measures the rate of deterioration of the evidence. $x\left(P^{t}\right)$ is the level of damages incurred by each firm in the current period where $\gamma$ is the damage multiple applied. While U.S. antitrust law specifies treble damages, $\gamma$ is often well less than three because of out-of-court settlements. $X^{t}$ is to be interpreted as that part of antitrust penalties that are sensitive to firms' prices and how long they've been colluding. Even though buyers cannot collect damages in the European Union, $X^{t}$ is still relevant as long as E.U. penalties are sensitive to cartel behavior. We will use a specification based on current U.S. antitrust practice:

$$
x\left(P^{t}\right)=\left(P^{t}-c\right) D\left(P^{t}\right)
$$

\footnotetext{
${ }^{2}$ One might be bothered that the payoff in the event of detection is negative and thus there is cause for a firm entering into bankruptcy. However, in most price-fixing cases, colluding firms have multiple products and collusion takes places in only a subset of those markets. Thus, the total value of the firm can remain positive even if they are caught colluding in some markets.
} 
where $c$ is the "but for price," that is, the price that would have occurred but for collusion. In the special case when the but for price is unit cost, damages equal the additional profits earned due to collusion.

It is assumed that damages are assessed only in periods of effective collusion. In particular, this means damages are not assessed in the period that a firm deviates. This has the useful implication that, at a symmetric equilibrium, all firms have identical damages and thus there is only one state variable for penalties, $X^{t}$. If we instead allowed damages to accumulate in the period that a firm deviated then accumulated damages for the deviator would differ from that of other firms which would require having a separate damage state variable for each firm. Our assumption strikes us a reasonable approximation and serves to reduce the number of state variables.

Successful prosecution of a cartel - by which is meant that penalties are imposed involves multiple stages. First, detection - the creation of suspicions that a cartel has formed. Some party - for example, buyers - must recognize that, among all of the thousands of industries, this particular one may be plagued by collusion. Second, investigation - in response to a complaint, the antitrust authority must decide that it is worthwhile to pursue a case. Third, prosecution - after conducting such an investigation, the antitrust authority must choose to prosecute the firms (and/or the buyers must decide whether to pursue civil damages litigation). The focus of our modelling is on detection. Detection of a cartel can occur from many sources, some of which are related to price - such as customer

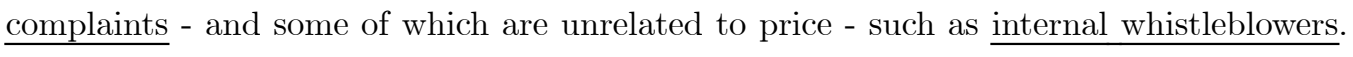
Hay and Kelley (1974) find that detection was attributed to a complaint by a customer or a local, state, or federal agency in 13 of 49 price-fixing cases. More recently, an investigation which uncovered the graphite electrodes cartel began with a complaint from a steel manufacturer which is a purchaser of graphite electrodes (Levenstein and Suslow, 2001), and the stainless steel case was launched by buyers complaining to the European Commission about the rapid increase in prices (Levenstein, Suslow, and Oswald, 2004). High prices or price increases or simply anomalous price movements may cause customers to become suspicious and pursue legal action or share their suspicions with the antitrust authorities. Though it isn't important for this model, we do imagine that buyers (in many price-fixing cases, they are industrial buyers) are the ones who may become suspicious about collusion.

To capture these ideas in a tractable manner, an exogenous probability of detection function is specified that depends on the current and previous periods' price vec- 
tors. $\phi\left(\underline{P}^{t}, \underline{P}^{t-1}\right)$ is the probability of detection when the cartel is active where $\underline{P}^{t} \equiv$ $\left(P_{1}^{t}, \ldots, P_{n}^{t}\right){ }^{3}$ It is assumed that, in the event of detection, successful prosecution occurs for sure so $\phi\left(\underline{P}^{t}, \underline{P}^{t-1}\right)$ also serves as the probability of paying penalties. ${ }^{4}$ We will consider a specification in which detection is sensitive to price changes. ${ }^{5}$ In light of the environment being stationary, buyers ought to be more surprised by bigger price increases as well as bigger price decreases.

With the Bertrand price game formulation, the transaction price in any period is the lowest price charged. Thus, it is assumed that detection depends on the movement in the lowest price in the market. Let $p^{t} \equiv \min \left\{P_{1}^{t}, \ldots, P_{n}^{t}\right\}$ denote the minimum price in period $t$. Making a notational change in the arguments of $\phi(\cdot)$, the probability of detection is specified to be quadratic in the change in the transaction price:

$$
\phi\left(p^{t}, p^{t-1}\right)= \begin{cases}\min \left\{\alpha_{0}+\alpha_{1}^{u}\left(p^{t}-p^{t-1}\right)^{2}, 1\right\} & \text { if } p^{t} \geq p^{t-1} \\ \min \left\{\alpha_{0}+\alpha_{1}^{d}\left(p^{t}-p^{t-1}\right)^{2}, 1\right\} & \text { if } p^{t}<p^{t-1}\end{cases}
$$

We then allow for an asymmetric response to price increases and price decreases and consider parameter values such that $0 \leq \alpha_{1}^{d} \leq \alpha_{1}^{u} . \phi\left(p^{t}, p^{t-1}\right)$ is assumed to apply to periods in which firms effectively collude. Cartel discovery may also take place after the cartel has collapsed. However, in light of the statute of limitations, this post-cartel window of discovery is bounded. Specifically, we assume, upon discontinuation of collusion, discovery can occur either in the period of collapse (that is, the period in which a firm deviates) or the period afterwards.

In the initial period, firms have the choice of forming a cartel, and risking detection and penalties, or earning non-collusive profit of $\widehat{\pi}$. If they choose the former, they can, at any time, choose to discontinue colluding. However, a finitely-lived cartel will cause collusion to unravel so that, in equilibrium, firms either collude forever or not at all (subject to the cartel being exogenously terminated because of detection).

In any period during which firms have a chance of being detected, a firm can apply to the corporate leniency program. This program allows the first firm to come forward to have a reduction in fines. Specifically, a firm awarded amnesty will only have to pay

\footnotetext{
${ }^{3}$ For an analysis where $\phi(\cdot)$ is derived, see Harrington and Chen (2004).

${ }^{4}$ Alternatively, one can allow the probability of successful prosecution, given detection, to lie between 0 and 1 where this probability is embedded in $\phi\left(\underline{P}^{t}, \underline{P}^{t-1}\right)$.

${ }^{5}$ We focus on the dependence of detection on price changes rather than price levels because optimal cartel price paths are more compelling. For this result as well as further motivation for this detection technology, see Harrington (2005b).
} 
a fraction $\theta \in[0,1]$ of the penalties levied, $X^{t}+F \cdot \theta=1$ captures the absence of any leniency program, while $\theta=0$ provides maximal leniency in that all penalties are avoided. If $m$ firms simultaneously apply for leniency, it is assumed that each has an equal chance of receiving it, in which case the expected fraction of penalties to be paid is $\frac{m-1+\theta}{m} .{ }^{6}$

Literature Review: Collusion and the Prospect of Cartel Detection An early work integrating the prospect of detection and penalties into the repeated game model of collusion is Cyrenne (1999) who modifies Green and Porter (1984) by assuming that a price war, and the ensuing raising of price after the war, results in detection for sure and with it a fixed fine. The first work to do so while making the probability of detection and penalties endogenous to the price path is Harrington (2005b). There the joint profit maximizing price path is characterized when incentive compatibility constraints are not binding. Assuming that the probability of detection is sensitive to price changes, the cartel is shown to gradually raises price with price converging to a steady-state level. Comparative statics on the steady-state price reveal that it is decreasing in the damage multiple and the probability of detection but is independent of the level of fixed fines. Furthermore, if penalties are independent of the price path then the cartel's steady-state price is the same as in the absence of antitrust laws. Another intriguing result is that a more stringent standard for calculating damages increases the steady-state price.

A characterization of the cartel price path when incentive compatibility constraints bind was conducted in Harrington (2004). Depending on the parameter values, two qualitatively distinct cartel price paths emerged. One is qualitatively the same as in Harrington (2005b) - the cartel gradually raises price and it converges to a steady-state level. This establishes that the monotonicity of the price path when incentive compatibility constraints do not bind extends to when they do. The second type of price path has the cartel gradually raise price but then price declines down to the steady-state. Though reducing price lowers profit and cannot make detection less likely, a price decline is required so as to maintain cartel stability. The impact of antitrust laws is also explored and analysis reveals a potentially perverse effect. Though making price-fixing illegal may induce a cartel to initially price lower, in some cases it may allow the cartel to eventually price

\footnotetext{
${ }^{6}$ Initially, we allowed the leniency parameter to vary according to the type of penalty so that a firm receiving amnesty would pay a penalty of $\theta_{d} X^{t}+\theta_{f} F$ where $\theta_{d}, \theta_{f} \in[0,1]$. A motivation for this is that, in the U.S., amnesty means all government fines are waived but a firm is still liable for single (not treble) damages. As the initial results did not reveal any interesting distinctions between $\theta_{d}$ and $\theta_{f}$, we chose to simplify matters and impose a common leniency parameter applicable to all sources of penalties.
} 
higher; this is due to how antitrust laws affect incentive compatibility constraints. The risk of detection and penalties may deter a firm from cheating, out of fear that a price war may generate suspicions about collusion. Thus, antitrust laws can loosen incentive compatibility constraints and thereby allow the cartel to set higher prices.

In the previous two papers (and in the current paper), a reduced form specification was used as the probability of detection was assumed to be increasing in price increases. A more foundational approach is taken in Harrington and Chen (2004) where buyers' beliefs are explicitly modelled and detection occurs when the observed price path is sufficiently unlikely in light of buyers' beliefs. In other words, suspicions emerge when observed prices are anomalous. The cartel price path is shown to be comprised of two phases. During the transitional phase, price is generally rising and relatively unresponsive to cost shocks. During the stationary phase, price responds to cost but is much less sensitive than under non-collusion or simple monopoly. Hence, the variance of price is much lower under collusion; a property consistent with the empirical work of Abrantes-Metz et al (2005). Furthermore, compared to when firms do not collude, cost shocks take a longer time to pass-through to price and this results in more serial correlation in prices. ${ }^{7}$

\section{Optimal Symmetric Subgame Perfect Equilibrium}

The cartel's problem is to choose an infinite price path so as to maximize the expected sum of discounted income subject to the price path being incentive compatible. In determining the set of incentive compatible price paths, the assumption is made that deviation from the collusive path results in the cartel being dissolved and firms behaving according to a Markov Perfect Equilibrium (MPE).

Suppose a firm deviates and the cartel collapses. Since cartel meetings are no longer taking place, the damage variable simply depreciates at the exogenous rate of $1-\beta$ : $X^{t}=\beta X^{t-1} .8$ This is still a dynamic problem, however, in that price movements can create suspicions and, while firms are no longer colluding, an investigation could reveal evidence of past collusion. It is assumed that discovery can occur either in the period during which a firm deviates or the period afterwards. The state variables at $t$ are last period's transaction price, denoted $p^{t-1}$, and (common) damages, $X^{t-1}$.

\footnotetext{
${ }^{7}$ There is earlier work which explores the prospect of detection in a static cartel model. These papers are referenced in Harrington (2005).

${ }^{8}$ Recall that we assume damages stop accumulating once collusion breakdowns which begins with the period in which a firm deviates.
} 
Given the Bertrand price formulation, it is easy to argue that a MPE must entail all firms pricing at the stage game equilibrium price of cost. ${ }^{9}$ Suppose, to the contrary, a (symmetric) MPE has all firms pricing at $P^{\prime}>c$ in the period after a deviation. By the usual argument, a firm could produce an $n$-fold increase in current profit by pricing just below $P^{\prime}$. As the change in the current price vector is arbitrarily small, there is almost no effect on the firm's future payoff since the change in the probability of detection is small and the change in the state variable is small. Since pricing a little below $P^{\prime}$ significantly raises current profit with almost no effect on future profits, it is not an equilibrium. Therefore, the MPE is infinite repetition of the stage game equilibrium which means the competitive price.

The cartel's problem is represented as a constrained dynamic programming problem:

$$
\begin{aligned}
V\left(p^{t-1}, X^{t-1}\right)= & \max _{P} \pi(P)-\delta \phi\left(P, p^{t-1}\right)\left[\beta X^{t-1}+\gamma x(P)+F\right] \\
& +\delta\left[1-\phi\left(P, p^{t-1}\right)\right] V\left(P, \beta X^{t-1}+\gamma x(P)\right)
\end{aligned}
$$

subject to

$$
\begin{aligned}
& \pi(P)-\delta \phi\left(P, p^{t-1}\right)\left[\beta X^{t-1}+\gamma x(P)+F\right] \\
& \quad+\delta\left[1-\phi\left(P, p^{t-1}\right)\right] V\left(P, \beta X^{t-1}+\gamma x(P)\right) \geq \\
& \max \left\{\max _{P^{\prime}<P} n \pi\left(P^{\prime}\right)-\delta \phi\left(P^{\prime}, p^{t-1}\right)\left(\beta X^{t-1}+F\right)+\delta\left[1-\phi\left(P^{\prime}, p^{t-1}\right)\right] W\left(P^{\prime}, \beta X^{t-1}\right),\right. \\
& \left.n \pi(P)-\delta \theta\left(\beta X^{t-1}+F\right)\right\} .
\end{aligned}
$$

A solution to (1)-(2) is referred to as an Optimal Symmetric Subgame Perfect Equilibrium (OSSPE). $W$ is the expected (non-collusive) payoff after a deviation and is defined by:

$$
W= \begin{cases}-\delta \phi\left(c, P^{\prime}\right)\left(\beta^{2} X^{t-1}+F\right) & \text { if } \theta \geq \phi\left(c, P^{\prime}\right) \\ -\delta\left(\frac{n-1+\theta}{n}\right)\left(\beta^{2} X^{t-1}+F\right) & \text { if } \theta<\phi\left(c, P^{\prime}\right)\end{cases}
$$

In the incentive compatibility constraint (2), a firm that cheats can choose to apply for amnesty in which case it pays penalties of $\theta\left(\beta X^{t-1}+F\right)$. Since detection is no

\footnotetext{
${ }^{9}$ This is not generally true and indeed does not hold under many differentiated products models in which the firm demand function is continuous. In that case, a firm may price above its static best reply function in order to reduce the size of the price decrease (from the collusive price) so as to reduce the chances of detection. This possibility is explored in Harrington (2004). Note that it is then possible that the MPE payoff could be higher than infinite repetition of the stage game equilibrium profit. What is required is that the higher profits (from prices being above the static equilibrium levels) more than compensate for the possibility of paying penalties. Sufficient conditions for that to occur are provided in Harrington (2003).
} 
longer an issue, it optimally prices so as to maximize current profit which means slightly undercutting the collusive price of $P$ and earning profit of approximately $n \pi(P)$. This yields a a payoff of $n \pi(P)-\delta \theta\left(\beta X^{t-1}+F\right)$. Alternatively, it can choose not to use the leniency program when it cheats. In that case, it may want to price differently so as to control the induced series of price decreases. If it deviates by pricing at $P^{\prime}$ then price will decline by $P^{\prime}-p^{t-1}$ in the current period and by $P^{\prime}-c$ in the following period. Note that it faces an expected present value of penalties of

$$
\delta \phi\left(P^{\prime}, p^{t-1}\right)\left(\beta X^{t-1}+F\right)+\delta^{2}\left[1-\phi\left(P^{\prime}, p^{t-1}\right)\right] \phi\left(c, P^{\prime}\right)\left(\beta^{2} X^{t-1}+F\right) .
$$

A deviating firm may then want to price lower than just undercutting the collusive price so that the price path falls more gradually and detection is made less likely.

In defining $W$, note that, as argued above, equilibrium necessarily entails all firms pricing at cost. The only issue is whether they apply for leniency (given the deviator did not already do so). It is always an equilibrium for all firms to apply for leniency. Given that all other firms do so, a firm reduces expected penalties from $\delta\left(\beta^{2} X^{t-1}+F\right)$ to $\delta\left(\frac{n-1+\theta}{n}\right)\left(\beta^{2} X^{t-1}+F\right)$ by doing so itself (where it is assumed that the firm given amnesty is randomly selected). There may also be another equilibrium in which no firm applies for amnesty. This exists if and only if $\phi\left(c, P^{\prime}\right) \leq \theta$ so that the probability of detection is weakly less than the fraction of penalties that must be paid if awarded amnesty. If the "no one applies for leniency" equilibrium exists, it is assumed that firms achieve it given it is Pareto superior to the equilibrium in which all firms apply. ${ }^{10}$

For when there is no corporate leniency program (that is, $\theta=1$ ), Harrington (2004) proves that an OSSPE price path exists, which may either have a cartel formed with prices above their static equilibrium levels or may involve no cartel formation. It is straightforward to show that the proof still works when $\theta<1$.

This modelling of detection is stationary and deterministic and thus is similar to that in, for example, Spagnolo (2003). The implication is that, in equilibrium, the leniency program is not used. For if it was used then collusion would end at a known finite date which would destabilize collusion in the initial period. Though the model of this paper allows the probability of detection to change over time because of its dependence on the price path, the probability moves in a deterministic manner so the same logic applies as in

\footnotetext{
${ }^{10}$ Note that $\phi\left(c, P^{\prime}\right) \leq \theta$ implies:$$
-\delta \phi\left(c, P^{\prime}\right)\left(\beta^{2} X^{t-1}+F\right)>-\delta\left(\frac{n-1+\theta}{n}\right)\left(\beta^{2} X^{t-1}+F\right) .
$$ 
Spagnolo (2003) and thus the leniency program is not used in equilibrium. This property is to be contrasted with the models of Motta and Polo (2003) and Harrington (2005a) where the probability of detection is stochastic. In that case, the leniency program can be used in equilibrium. Though we believe such a stochastic specification is more compelling, tractability prevents that level of richness here.

When colluding firms do not anticipate using the leniency program in equilibrium, leniency operates exclusively through the payoff to cheating in the incentive compatibility constraint. As a deviating firm can receive amnesty from some or all penalties, the standard argument in previous papers is that the payoff to cheating is (weakly) higher, while the payoff to colluding is unaffected (since firms do not apply for amnesty in equilibrium). ${ }^{11}$ Hence, leniency programs make cheating relatively more profitable and this serves to reduce cartel stability.

It is true in this model as well that the possibility of a deviating firm lowering its penalty through amnesty can raise its payoff and thus make collusion more difficult. However, there are two points to make. First, the effect is more complex here since the price a firm charges when it deviates is endogenous and thus can depend on whether or not it applies for amnesty. If it decides to receive leniency then a deviating firm need not be concerned about a post-deviation price war triggering detection. As a result, it can maximize its profit from cheating by just undercutting the collusive price. With this richer oligopoly model, leniency affects not only the penalties paid by a firm that deviates but also the profits it receives when it does deviate.

Previous models assume that detection can occur only when firms are colluding. We depart from this assumption by allowing detection to occur in the period after the cartel's collapse (that is, the period after which a firm deviates). This leads us to the second point which is that expected penalties can be higher when partial leniency is offered, compared to a policy of no leniency. Suppose a firm that deviates finds it optimal not to use the leniency program, perhaps because the probability of detection is relatively low (even for big price decreases). Further suppose that, in the period after the deviation, it is an equilibrium for all firms to apply for leniency. Of course, if that event was anticipated, a deviating firm would generally prefer to apply for leniency when it deviates because,

${ }^{11}$ The latter property is not true when the probability of detection is stochastic as shown in Motta and Polo (2003) and Harrington (2005a). In that colluding firms anticipate that they may use leniency in the future (in the event that the probability of discovery is sufficiently high), the expected collusive payoff depends on the leniency program as well. While more leniency raises the expected collusive payoff in Motta and Polo (2003), it can either raise or lower the expected payoff in Harrington (2005a). 
by doing so, it receives amnesty for sure, while if it waits then it only receives it with probability $\frac{1}{n}$. The implication of this argument is that a deviating firm may use the leniency program even though the ensuing payoff is lower than when there is no leniency program. For some values of $\theta$, it is then possible that leniency reduces the payoff to cheating and, therefore, it is not immediate that more leniency (a lower value for $\theta$ ) reduces cartel stability. This argument, however, only pertains to when $\theta>>0$. When $\theta \simeq 0$ then a deviating firm who applies for leniency pays a penalty close to zero and that has to be less than what is paid in the absence of a leniency program. Hence, a policy of maximal leniency necessarily tightens the incentive compatibility constraint relative to having no leniency program. Whether there is a monotonic relationship - waiving a higher fraction of penalties under the leniency program makes collusion more difficult to sustain - is less clear.

\section{Numerical Analysis}

To begin, let us describe the method used to solve (1)-(2). The price-damage state space is $\Delta \equiv\left[0, P^{m}\right] \times\left[0, \gamma x\left(P^{m}\right) /(1-\beta)\right]$, where $P^{m}$ is the simple monopoly price. $\Delta^{*}$ is a discretized version of $\Delta$ which is $30 \times 30$ and thus has 900 states. (1)-(2) is solved through function iteration on $\Delta^{*}$. The value function is approximated by a linear spline with 30 basis functions and an equal number of interpolation nodes. One specifies an initial value function and then uses (1)-(2) to produce a new value function for each state in $\Delta^{*}$. Interpolation using a linear spline then produces a new value function defined on $\Delta$. This process is iterated until convergence is achieved where the criterion is the norm of the difference of the coefficient vectors between iterations and the tolerance level is $5 \times 10^{-10} .{ }^{12}$

There are a total of 12 parameters. Putting aside the leniency parameter, the benchmark parameter configuration is:

$$
\begin{aligned}
& a=100, b=1, c=0, \delta=.7, \beta=.9, n=3 \\
& \gamma=1, F=0, \alpha_{0}=.05, \alpha_{1}^{u}=.0032, \alpha_{1}^{d}=.0016
\end{aligned}
$$

Note that the simple monopoly price is 50 and the non-collusive price is 0 . We solved both the unconstrained case, (1), and the constrained case, (1)-(2) for $\theta=.2$. The associated value and policy functions are shown in Figure 1. For the unconstrained case (and note

\footnotetext{
${ }^{12}$ For details on these numerical methods, see Judd (1999) and Miranda and Fackler (2002).
} 
that leniency is irrelevant), the policy function is monotonic in the two states. The higher is the previous period's transaction price, the higher the cartel can set price in the current period since the resulting price increase is not as large. As accumulated damages are smaller, the penalty in the event of discovery is smaller which makes the cartel want to raise price more. This reflects the trade-off from a bigger price increase: A higher current profit but a lower future payoff since the probability of detection and accumulated damages are higher.

Turning to the solution to the constrained problem, the policy function is similar except when last period's price is relatively high and damages are relatively low; for those states, the incentive compatibility constraint is violated so firms set the stage game equilibrium price of zero. When price is relatively high, firms have an incentive to cheat in order to earn higher current profit. In order to counteract that incentive, the cartel must lower price significantly. But if that occurs then the probability of detection is high - since there is a large price decrease - in which case the expected future lifetime is short and that induces firms to cheat. As a result, there is no collusive price that is stable and so the policy function prescribes a price equal to cost. However, when damages are high, firms are so concerned about not inducing detection that this stifles the incentive to cheat and thus collusion can be maintained even if the inherited price is rather high. Note that price also tends to be lower near the interface of these two regions - the region for which collusion collapses and the region for which the incentive compatibility constraint doesn't bind so the unconstrained solution can be sustained. Around that interface, the incentive compatibility constraint can be satisfied but only by pricing below the unconstrained solution.

To explore the effect of the leniency policy on cartel behavior, (1)-(2) was solved for all $\theta \in\{0, .1, \ldots, 1\}$. With initial conditions of the cartel's price equalling the noncollusive price and damages equalling zero, we then determined whether cartel formation was optimal and, if it was, the optimal cartel price path. The analysis showed that (2) is unaffected by $\theta$ when $\theta \geq .3$. We then solved (1)-(2) for a finer grid: $\theta \in\{0, .01, \ldots, .3\}$. Cartel formation was found to be unsustainable when $\theta<.18$. For $.18 \leq \theta$, firms are able to form a cartel. When $.26 \leq \theta$, firms form a cartel and the resulting cartel price path is very close to the unconstrained optimum so the leniency program is having a minimal effect or perhaps no effect at all as a deviating firm would not use it. Figure 2 then focuses on the cartel price path for $\theta \in\{.18, .20, \ldots, .24\}$. The price path steadily rises as firms balance off higher profit and a higher chance of getting caught in determining the rate at 
which to increase price. Note that it converges to a steady-state level which is below the simple monopoly price of $50 .{ }^{13}$ As the policy becomes more lenient - so that more fines are waived to the first firm to come forward (that is, $\theta$ is reduced) - the cartel price path shifts down. Though the steady-state price is left unaffected, it takes a longer time for the cartel to reach it. As $\theta$ is lowered, the incentive to cheat becomes stronger - as a firm that cheats can acquire amnesty and avoid a larger portion of penalties - and the cartel must respond by lowering price so as to ensure that cheating is not optimal.

The next exercise characterizes the effect of leniency on cartel formation by deriving the minimum discount factor at which a cartel forms. For both $\theta=.3$ and $\theta=1$, (1)-(2) was solved for all $\delta \in\{0, .01, \ldots, .99,1\}$. For both leniency parameter values, a cartel formed only when $\delta \geq .66$. We inferred that this is true for all $\theta \geq .3$ and then focused on $\theta<.3$. For each $\theta \in\{0, .01, \ldots, .29\},(1)$-(2) was solved for a low value of $\delta$ and re-solved for a progressively higher value of $\delta$ until cartel formation emerged. Figure 3 reports the results. The minimum discount factor rises with the extent of leniency until the discount factor has to be at least .86 when there is maximal leniency. Waiving a higher fraction of fines makes it more difficult for a cartel to form. These results support earlier theoretical findings, in the context of a Prisoners' Dilemma, that more leniency makes collusion more difficult.

Similar exercises were performed for other parameter configurations. Figure 4 reports results for $n=4$ and $\delta=.8$, Figure 5 for $n=5$ and $\delta=.85$, and Figure 6 for $n=6$ and $\delta=.9$. The same pattern emerges: a more lenient policy (lower $\theta$ ) causes the cartel price path to shift down. In addition, when $\theta$ is sufficiently low then a cartel does not form. Though not reported here, the property in Figure 3 also holds: cartel formation is more difficult when there is more leniency. Figures 7 and 8 report results for a higher damage multiple and a lower minimum value to the probability of detection. Figure 7 has $\gamma=2$ and $\alpha_{0}=.04$, while Figure 8 has $\gamma=3$ and $\alpha_{0}=.03$. The same qualitative results emerge.

In sum, results thus far show that when leniency is sufficiently great, firms are unable to

\footnotetext{
${ }^{13}$ As explained in Harrington (2004), this arises for two reasons. First, a cartel will not want to set the monopoly price as long as penalties are sensitive to that price. By marginally lowering price below the monopoly price, there is no first-order effect on current profit but there is a first-order effect in reducing damages. However, if the only penalty is a fixed fine, then this force is not operative so the cartel would indeed want to price at the simple monopoly price. Second, even if the cartel wants to price at the simple monopoly price it may not be able to because the incentive to cheat is too great and thus incentive compatibility constraints are violated. This induces them to set a lower steady-state price.
} 
form a cartel. When it is sufficiently mild, firms cartelize and leniency has no effect since a deviating firm would not use it. For an intermediate range of leniency parameter values, a cartel forms but the price path is shifted down in response to a higher fraction of penalties being waived. It follows from these lower prices that the value to colluding is lower when the leniency program is stronger (that is, the fraction of fines waived is larger). These results are consistent with the cartel-destabilizing effects of leniency programs found, for example, by Motta and Polo (2003) and Spagnolo (2003).

The next set of results tell a different story. When the probability of detection is weak, the provision of partial leniency can serve to enhance collusion, though maximal leniency continues to make cartel formation more difficult. For purposes of comparison, let us report the value to forming a cartel under the benchmark parameter configuration. Figure 9 shows that value which is the value function evaluated at the initial conditions, that is, the expected present value of the profit stream from forming a cartel. (Keep in mind that the non-collusive value is zero.) Consistent with the price path shifting down when $\theta$ is reduced, the collusive value is lower when there is a more generous leniency policy. More leniency is making collusion less profitable. Figure 9 also reports the value of forming a cartel when there is no leniency program. Note that the two values - with and without a leniency program - converge when leniency is sufficiently weak which is due to leniency not having an impact as it is not used.

Let us now reduce the probability of detection by setting $\left(\alpha_{1}^{u}, \alpha_{1}^{d}\right)=(.00032, .00016)$, while maintaining all other benchmark parameter values. The resulting value to colluding is reported in Figure 10. When $\theta \leq .16$ and thus a sufficiently high fraction of penalties is waived, a leniency program has the desired impact of preventing cartel formation. Notice that the value to colluding is positive in the absence of leniency so a cartel would form otherwise. When $\theta=.18$, a cartel forms but the collusive value is around 1000 and thus lower than when there is no leniency when it is over 1300. In that case, partial leniency is making deviation more attractive and this reduces the cartel price path and thus lowers the value to colluding. However, for $\theta \in\{.22, .24\}$, the value to forming a cartel is actually higher when a leniency program is in place. This must be due to the possibility that firms will apply for leniency after the cartel collapses and this serves to raise expected penalties from cheating.

To see the argument, suppose a firm that deviates would prefer not to apply for amnesty because the probability of detection is relatively low given its optimal deviation price. What is possible, however, is that, in the period after deviation, it is an equilibrium 
for all firms to apply for leniency. The reason is that firms reduce price to marginal cost and this sharp price drop results in a sufficiently large probability of detection so as to make it optimal for a firm to apply for leniency given all other firms do not. Hence, the only equilibrium has all firms applying for leniency after the cartel collapses. Of course, a firm that is contemplating a deviation would anticipate this event and apply for leniency itself when it deviates. By doing so, it receives amnesty for sure, while if it waits then it only receives it with probability $\frac{1}{n}$. The implication of this argument is that a deviating firm may use the leniency program even though its payoff is lower compared to when there is no leniency program. The presence of a leniency program then raises expected penalties when a firm cheats and this reduces the payoff to cheating, loosens the incentive compatibility constraint, and allows the cartel to set higher prices. The resulting higher cartel price path is depicted in Figure 11 for $\theta=.22$.

Contrary to our earlier findings and to much of the literature, partial leniency programs - so that some but not all penalties are waived - can enhance the attractiveness of forming a cartel. What is robust is that maximal leniency always serves to destabilize cartels. Though the policy of the European Commission is one of maximal leniency to the first firm to come forward, it is only partial leniency in the U.S. The U.S. program waives all government penalties but cartel members are still liable for private customer damages and thus the program is effectively one of partial leniency. Recently, the Antitrust Criminal Penalty Enforcement and Reform Act of 2004 expanded leniency in that a firm is now only liable for single, rather than the usual treble, damages (which corresponds to a lower value for $\gamma$ for the firm that enters the leniency program). Still, leniency remains partial though is now closer to maximal leniency.

\section{Summary}

A major challenge to stopping cartels is that they are shrouded in secrecy. The corporate leniency program works to break the code of silence among cartel members. Research exploring the effect of such programs grows as more countries adopt them and as more convictions are attributed to the existence of such programs.

This study brings together two recent strands of the collusive pricing literature. One strand explores the impact of corporate leniency programs using a very simple specification in which oligopolistic interaction is modelled as a Prisoners' Dilemma and both the penalty and probability of detection are exogenous to cartel behavior. This simple oligopolistic 
structure implies that a leniency program can have an impact only by deterring cartel formation; it cannot influence the price path in the event of cartel formation as only one collusive price is presumed feasible. The second strand explores the impact of antitrust enforcement on collusive pricing by modifying the classical repeated game setting so as to allow detection of the cartel - by buyers or authorities - to be sensitive to the price path. Blending these two strands, this paper investigates the impact of a leniency program when the cartel can manipulate the price path so as to influence the likelihood of detection and penalties in the event of detection. Thus, the analysis is able to describe how such programs influence the cartel price path as well cartel formation.

Through numerical analysis, several conclusions are drawn. First, we found that, consistent with earlier results, maximal leniency programs (whereby all penalties are waived to the first firm to come forward) necessarily makes collusion more difficult. Second, in most (but not all) cases, the collusive value of cartel is lower when there is a more generous leniency policy (that is, a higher fraction of penalties are waived). A more lenient program provides a stronger incentive for a cartel member to cheat as it can avoid penalties by simultaneously applying for amnesty when it undercuts the collusive price. This tightens the incentive compatibility constraint which induces the cartel to price lower. Hence, even if a leniency program is unsuccessful in deterring cartel formation, it may still be able to cause the cartel to price lower in order to maintain cartel stability. The third result provides a caveat to the result just mentioned in that partial leniency programs (such as is used in the U.S.) can have a perverse effect on antitrust enforcement. When the probability of detection is weak, the collusive value can be higher when a partial leniency program is put in place (compared to offering no leniency program). In response to a firm cheating, firms may excessively use the leniency program and, given that only one firm can receive amnesty, expected penalties can actually be higher with partial leniency. This serves to reduce the payoff to cheating which permits the cartel to sustain a higher

price path. Leniency programs can then have subtle perverse effects though, on net, our analysis suggests that they do indeed tend to make collusion more difficult.

\section{References}

[1] Abrantes-Metz, Rosa M., Luke M. Froeb, John F. Geweke, and Christopher T. Taylor, "A Variance Screen for Collusion," Federal Trade Commission, March 2005. 
[2] Aubert, Cécile, Patrick Rey, and William Kovacic, "The Impact of Leniency Programs on Cartels," University of Toulouse, November 2003.

[3] Cyrenne, Philippe, "On Antitrust Enforcement and the Deterrence of Collusive Behavior," Review of Industrial Organization, 14 (1999), 257-272.

[4] Feess, Eberhard and Markus Walzl, "An Analysis of Corporate Leniency Programs and Lessons to Learn for US and EU Policies," University of Maastricht, September 2004.

[5] Green, E. and Porter, R.H. "Noncooperative Collusion under Imperfect Price Information," Econometrica, Vol. 52 (1984), pp. 87-100.

[6] Harrington, Joseph E. Jr., "Some Implications of Antitrust Laws for Cartel Pricing," Economics Letters, 79 (2003), 377-383.

[7] Harrington, Joseph E. Jr., "Cartel Pricing Dynamics in the Presence of an Antitrust Authority," RAND Journal of Economics, 35 (2004), 651-673.

[8] Harrington, Joseph E. Jr., "Optimal Corporate Leniency Programs," Johns Hopkins University, March 2005a.

[9] Harrington, Joseph E. Jr., "Optimal Cartel Pricing in the Presence of an Antitrust Authority," International Economic Review, 46 (2005b), 145-169.

[10] Harrington, Joseph E. Jr. and Joe Chen, "Cartel Pricing Dynamics with Cost Variability and Endogenous Buyer Detection," Johns Hopkins University, December 2004 (International Journal of Industrial Organization, forthcoming).

[11] Hay, George and Daniel Kelly, "An Empirical Survey of Price Fixing Conspiracies," Journal of Law and Economics, 17 (1974), 13-38.

[12] "Hard Core Cartels," OECD Report, 2003.

[13] Judd, Kenneth L., Numerical Methods in Economics, Cambridge, Mass.: The MIT Press, 1999.

[14] Kobayashi, Bruce H., "Antitrust, Agency and Amnesty: An Economic Analysis of the Criminal Enforcement of the Antitrust Laws Against Corporations," George Washington Law Review, 69 (2001), 715-744. 
[15] Levenstein, Margaret and Valerie Suslow, "Private International Cartels and Their Effect on Developing Countries," University of Massachusetts, pdf copy, 2001.

[16] Levenstein, Margaret C., Valerie Y. Suslow, and Lynda J. Oswald, "Contemporary International Cartels and Developing Countries: Economic Effects and Implications for Competition Policy," Antitrust Law Journal, 71 (2004), 801-852.

[17] Miranda, Mario J. and Paul L. Fackler, Applied Computational Economics and Finance, Cambridge, Mass.: The MIT Press, 2002.

[18] Motchenkova, Evguenia, "The Effects of Leniency Programs on the Behavior of the Firms Participating in Cartel Agreements," Tilburg University, 2004.

[19] Motta, Massimo and Michele Polo, "Leniency Programs and Cartel Prosecution," International Journal of Industrial Organization, 21 (2003), 347-379.

[20] Spagnolo, Giancarlo, "Divide et Impera: Optimal Deterrence Mechanisms Against Cartels and Organized Crime," University of Mannheim, March 2003. 


\section{Figure 1. Benchmark Parameter Specification}
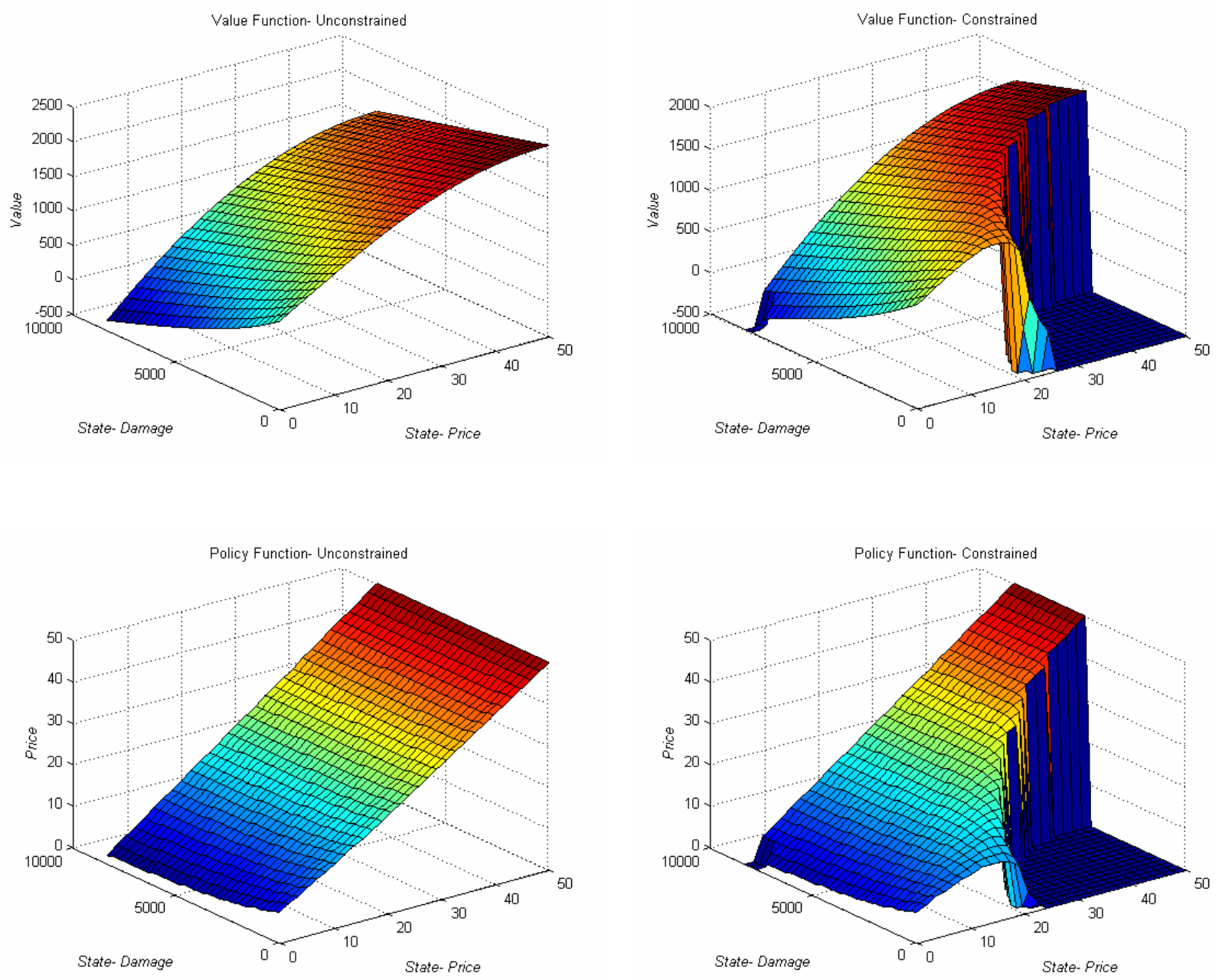
Figure 2. Simulated Price Paths

Benchmark Parameter Specification

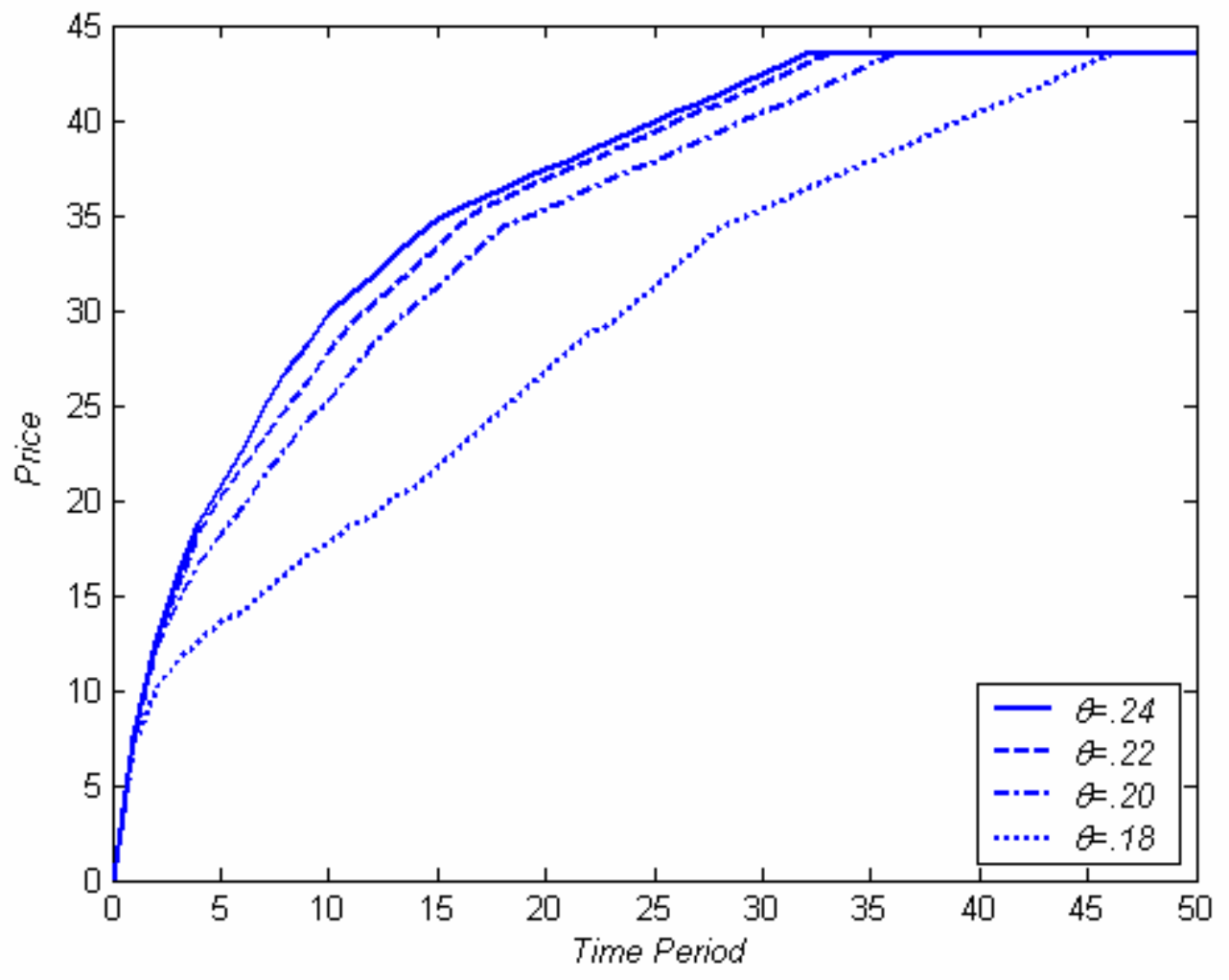


Figure 3. Minimum Discount Factor for Cartel Formation

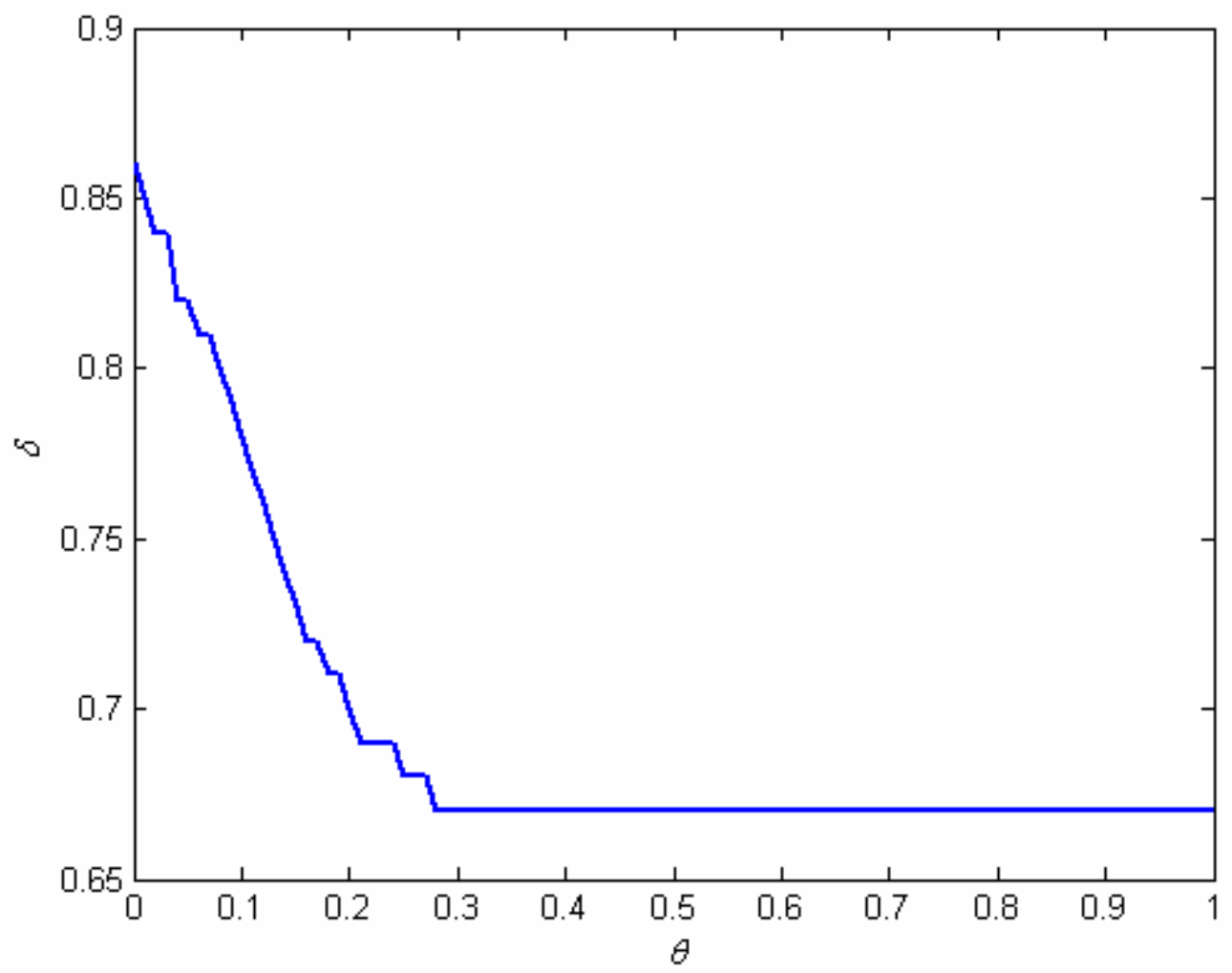


Figure 4. Simulated Price Paths

$$
(n=4, \delta=.8)
$$

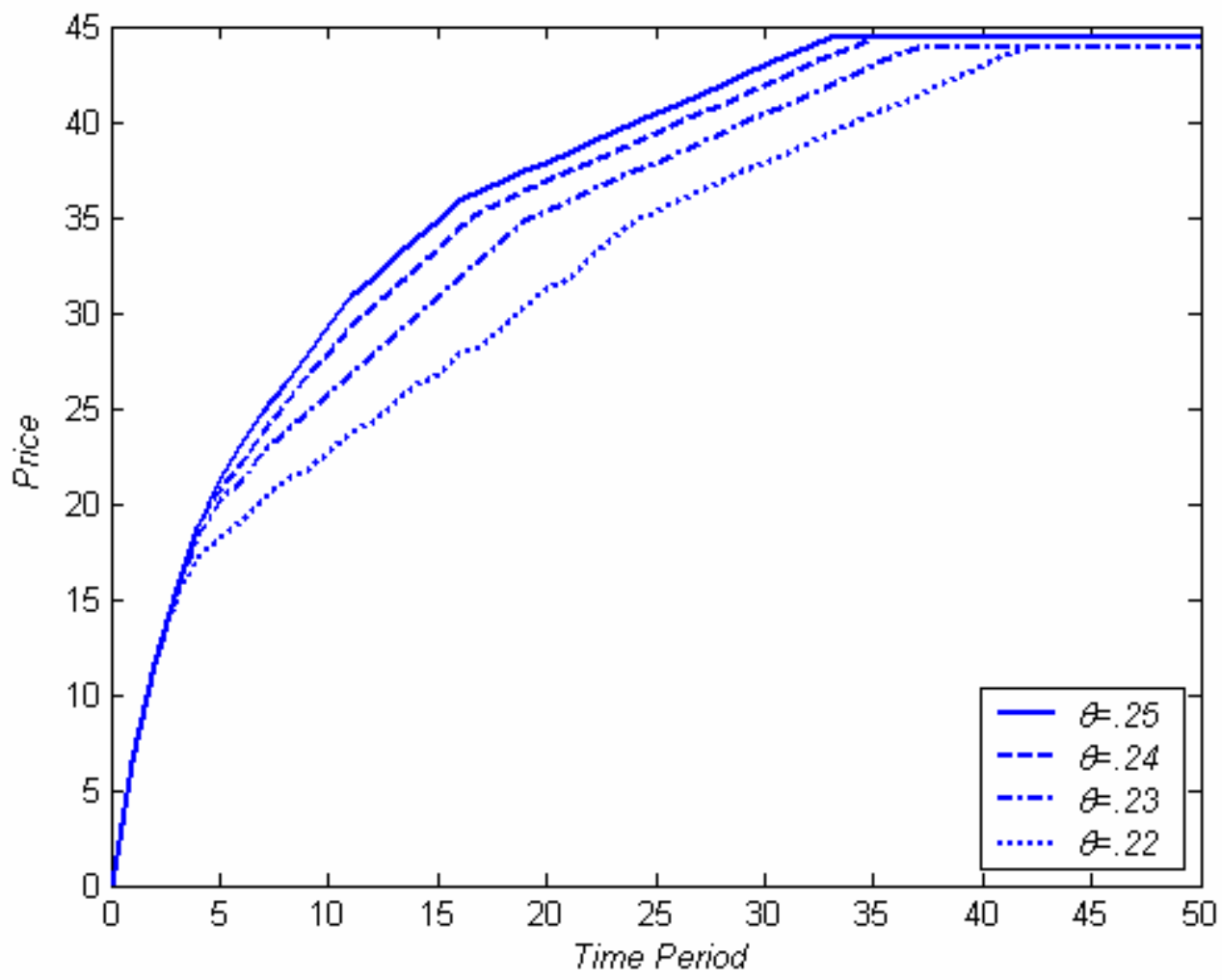


Figure 5. Simulated Price Paths

$$
(n=5, \delta=.85)
$$

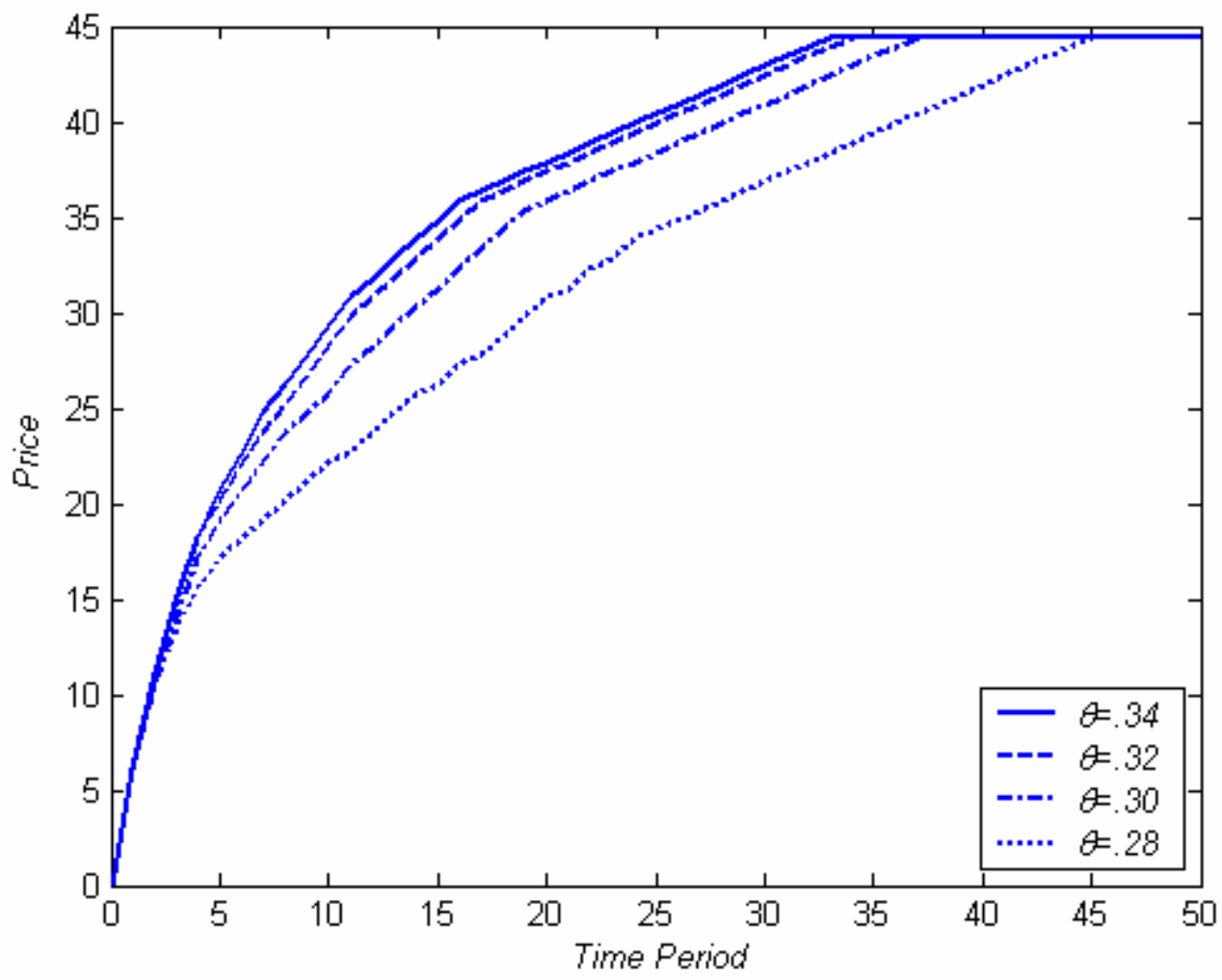


Figure 6. Simulated Price Paths

$$
(n=6, \delta=.9)
$$

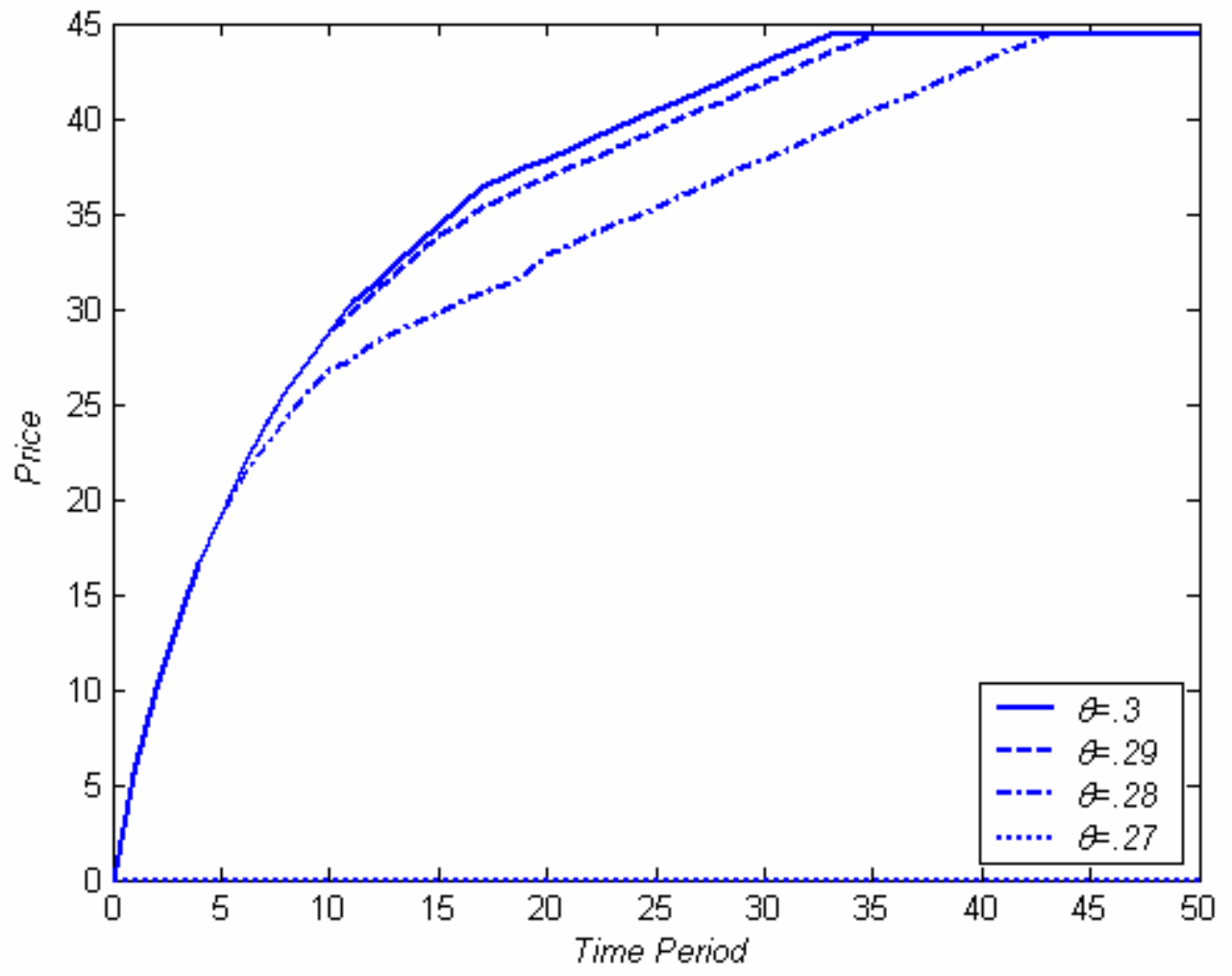


Figure 7. Simulated Price Paths

$$
\left(\gamma=2, \alpha_{0}=.04\right)
$$

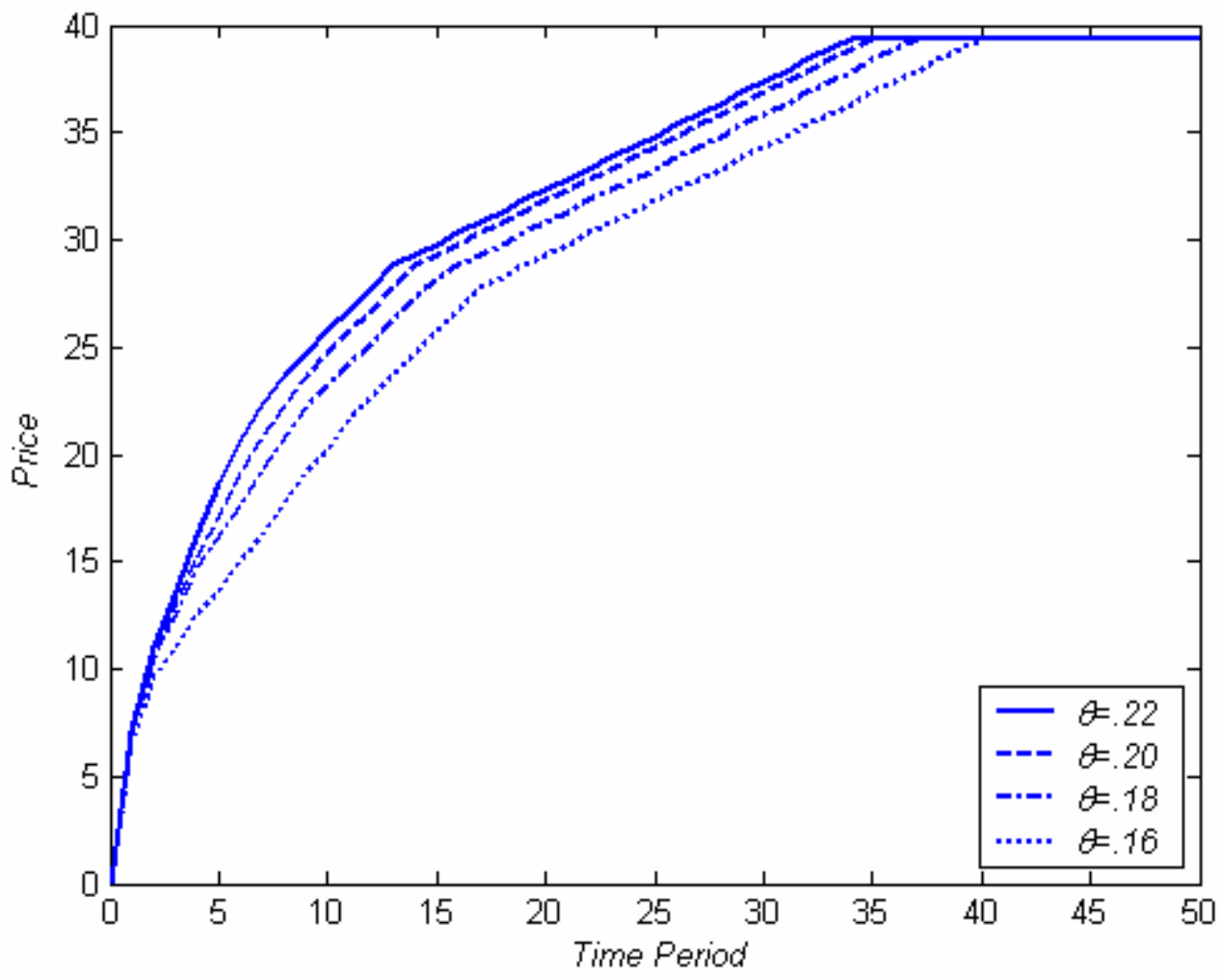


Figure 8. Simulated Price Paths

$$
\left(\gamma=3, \alpha_{0}=.03\right)
$$

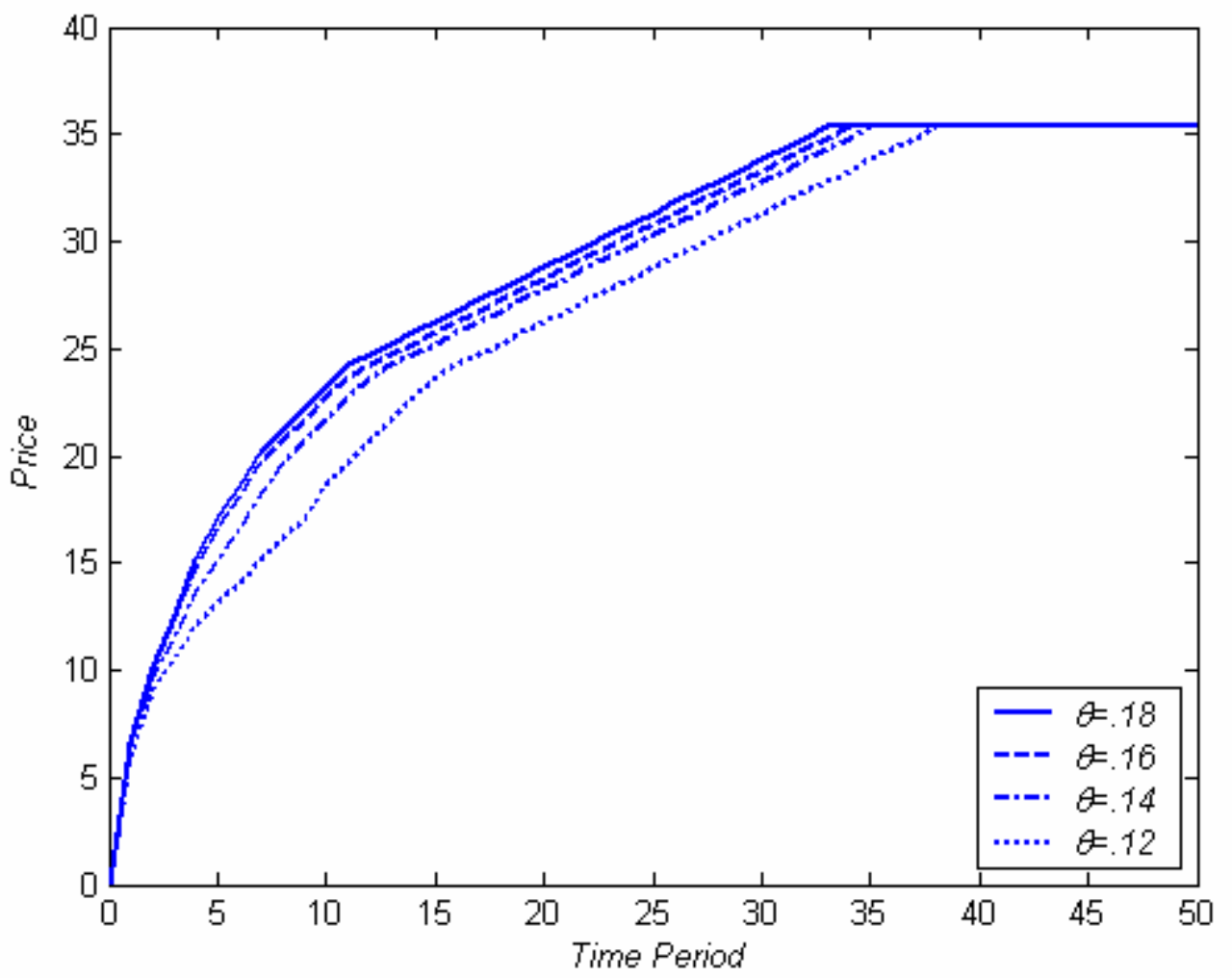


Figure 9. Collusive Value: Benchmark Parameter Specification

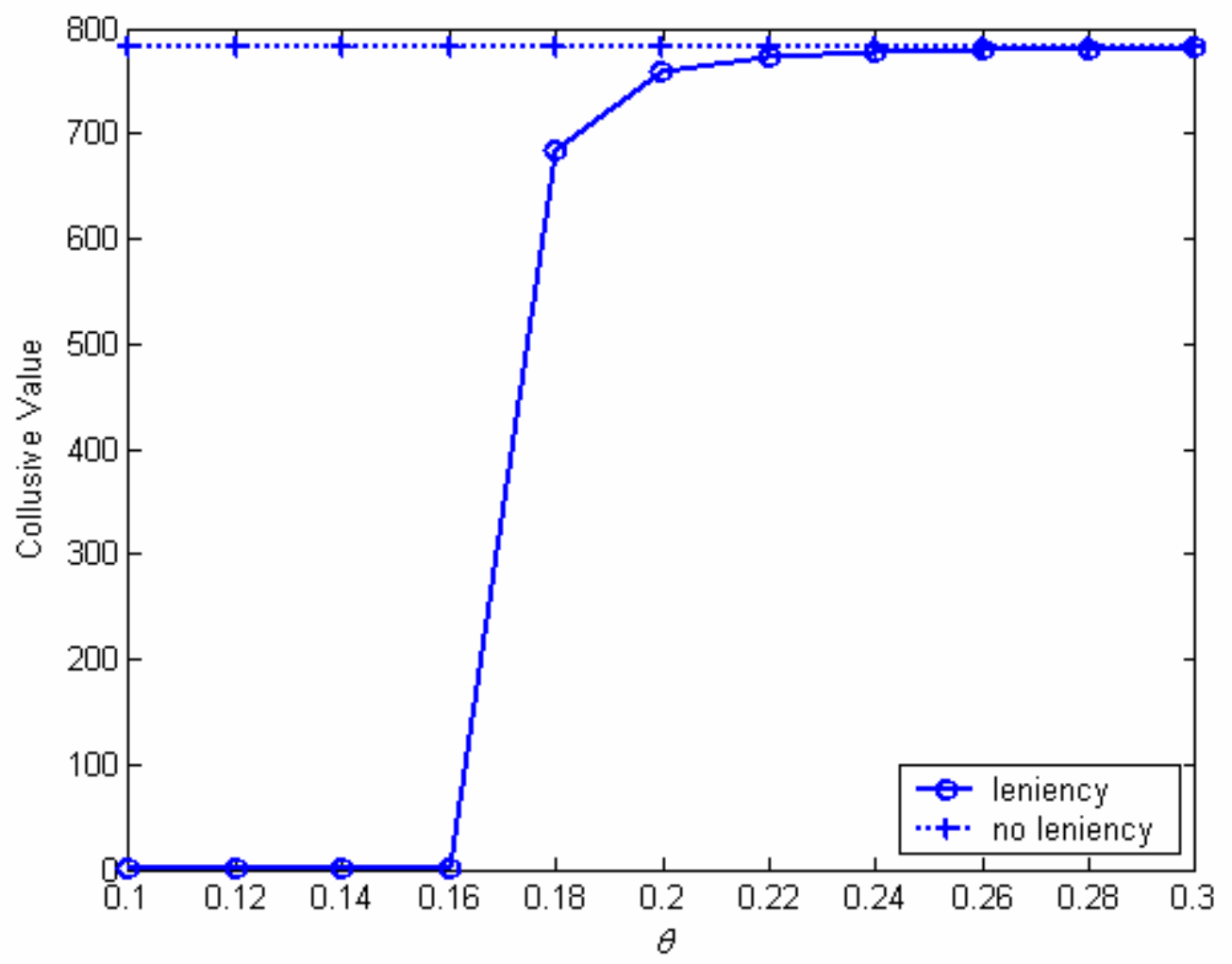


Figure 10. Collusive Value: Weak Probability of Detection

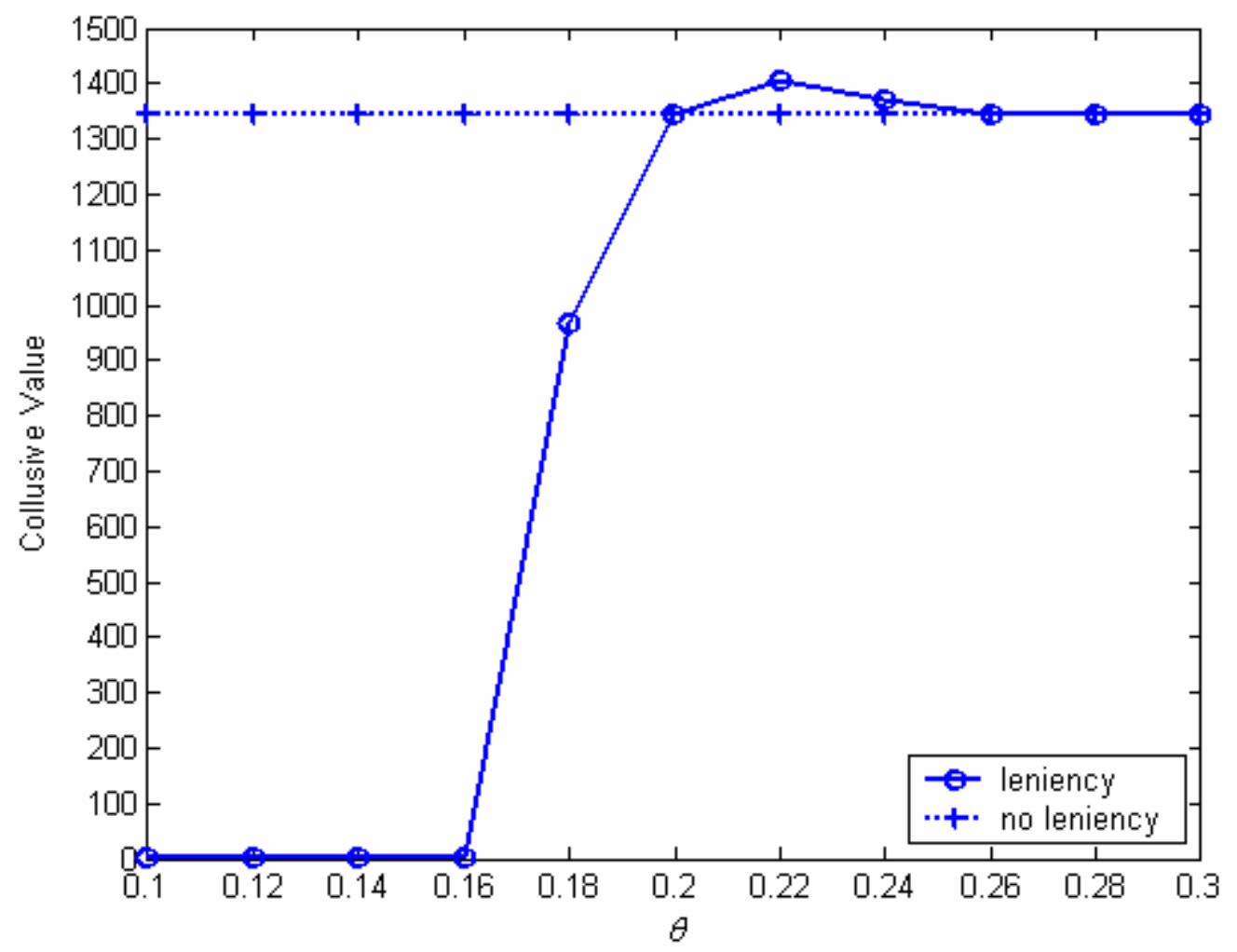


Figure 11 Simulated Price Paths: Weak Probability of Detection

$$
(\theta=.22)
$$

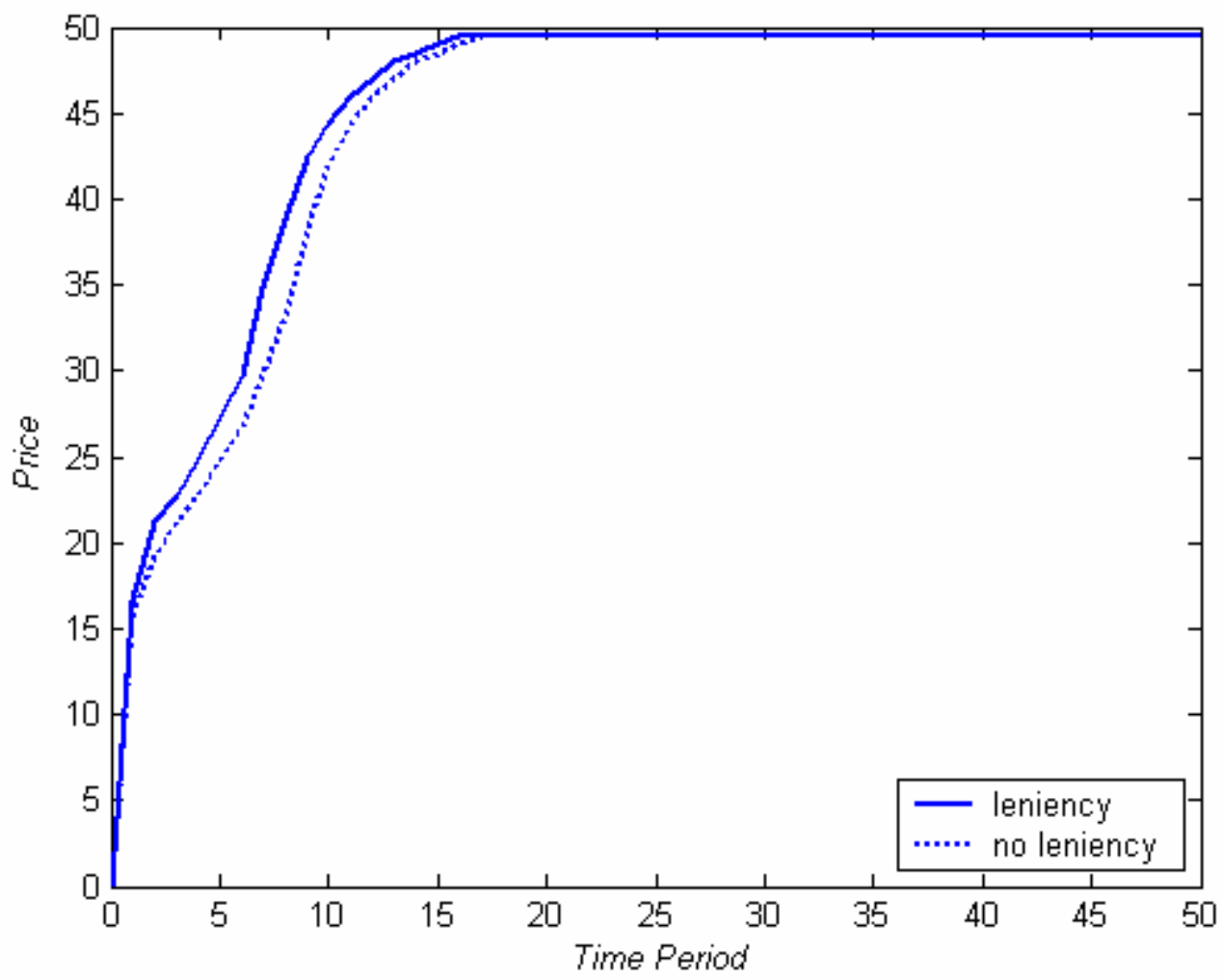




\section{Keywords for the End-of-volume Index}

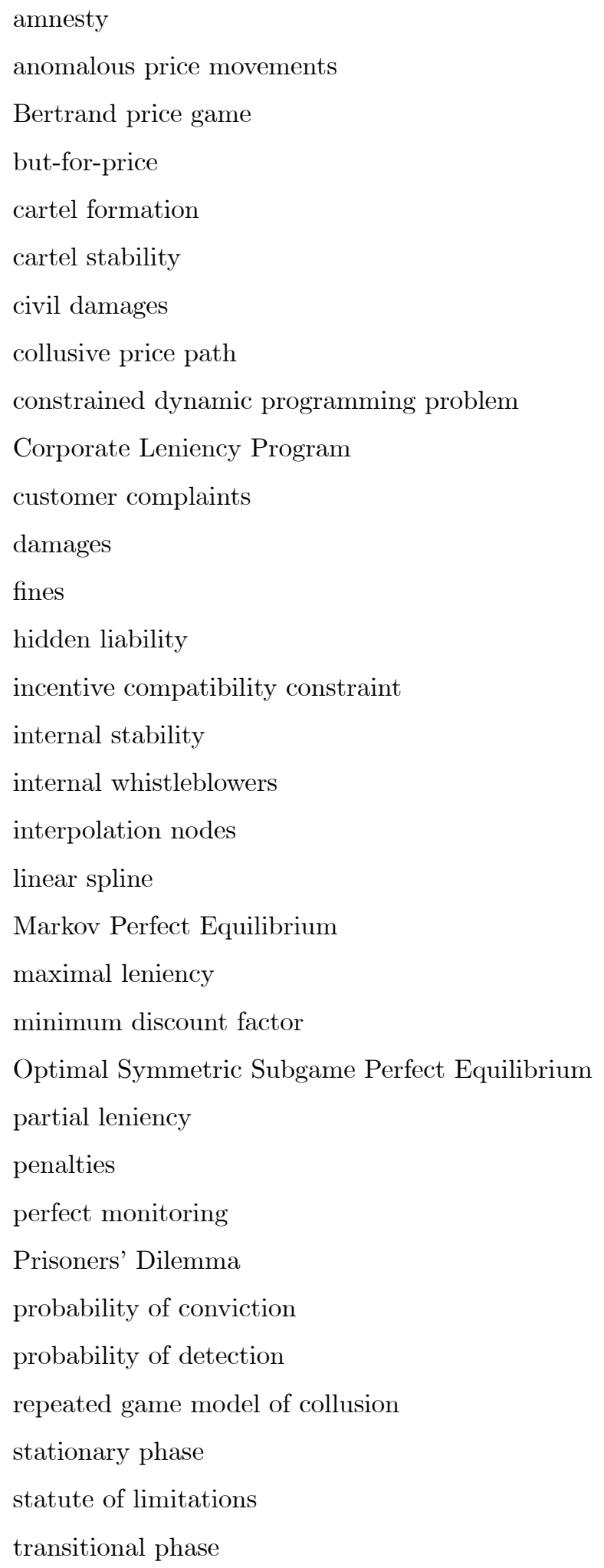


treble damages 